\title{
Pricing shares in equity crowdfunding
}

\author{
Lars Hornuf • Matthias Neuenkirch
}

Accepted: 27 September 2016/Published online: 25 October 2016

(C) The Author(s) 2016. This article is published with open access at Springerlink.com

\begin{abstract}
We analyze the pricing of cash flow rights in start-up companies using a unique data set of 44 equity crowdfunding campaigns. Our sample consists of 499 backers who invested during the period from November 6, 2011, to March 25, 2014, on the German equity crowdfunding portal Innovestment. In contrast with all other European equity crowdfunding portals, Innovestment runs a multi-unit second-price auction in which backers themselves can specify the price of an investment ticket. We exploit this unique auction mechanism to analyze backers' willingness to pay for cash flow rights. We find that campaign characteristics, investor sophistication, progress in funding, herding, and stock market volatility influence backers' willingness to pay in an economically meaningful manner, while geographic distance, learning effects, and sniping at the end of an auction have no effect.
\end{abstract}

Keywords Auctions · Equity crowdfunding · Valuation of shares

JEL Classifications $\quad$ D44 $\cdot$ G11 $\cdot$ M13 $\cdot$ L26

L. Hornuf · M. Neuenkirch

Department of Economics, University of Trier,

54286 Trier, Germany

e-mail: neuenkirch@uni-trier.de

L. Hornuf $(\square)$

Max Planck Institute for Innovation and Competition,

80539 Munich, Germany

e-mail: lars.hornuf@ip.mpg.de

\section{Introduction}

Around the globe, lawmakers are taking actions to bring equity crowdfunding under a specific legal umbrella. Equity crowdfunding (also referred to as investment-based crowdfunding, securities crowdfunding, or crowdinvesting ${ }^{1}$ ) constitutes a financial innovation in securities issuance that gives small entrepreneurs access to the general public. Regulatory efforts often pursue the objective to facilitate entrepreneurial activities while also putting a minimum level of investor protection in place. To balance this trade-off, regulators must consider the actual behavior

\footnotetext{
${ }^{1}$ In this paper, we refer to the new asset class as equity crowdfunding, as this is the term most frequently used in the literature. See also the JOBS Act, which includes the term 'crowdfunding' referring to transactions involving the offer or sale of a security, and Ahlers et al. (2015, p. 955), who define the term 'equity crowdfunding' as a 'form of financing in which entrepreneurs make an open call to sell a specified amount of equity or bond-like shares in a company on the Internet'. The FCA Consultation Paper CP13/13 'The FCA's regulatory approach to crowdfunding (and similar activities)' and the European Securities and Markets Authority 'Opinion Investment-based crowdfunding' use the term 'investment-based crowdfunding'. Knight et al. (2012) and the US Securities and Exchange Commission (17 CFR Parts 200, 227, 232 et al. Crowdfunding, Proposed Rule) refer to this new activity as 'securities crowdfunding'. The term 'crowdinvesting' is probably the most useful, as it encompasses all financial instruments found in practice, regardless of whether they are classified as securities or investments or lack a legal definition altogether (Klöhn and Hornuf 2012).
} 
of investors in these markets. In this paper, we investigate how backers price the value of cash flow rights in a start-up company when engaging in an equity crowdfunding campaign, using a unique data set of Innovestment backers.

Prior studies on Internet-based entrepreneurial finance have mainly focused on donation-based crowdfunding (Bøg et al. 2012; Burtch et al. 2013; Koning and Model 2013; Meer 2014; Saxton and Wang 2014), reward-based crowdfunding (Agrawal et al. 2013; Belleflamme et al. 2014; Colombo et al. 2015; Kuppuswamy and Bayus 2014; Marom and Sade 2013; Mollick 2013, 2014; Younkin and Kashkooli 2013; Zvilichovsky et al. 2013), and crowdlending (Burtch et al. 2014; Lin et al. 2012; Lin and Viswanathan 2013). In one of the first studies on equity crowdfunding, Agrawal et al. (2013) analyze the revenue-sharing model of Sellaband. Under the Sellaband model, backers receive a portion of the future returns that an artist generates by producing music. Ahlers et al. (2015) investigate investors on the Australian equity portal ASSOB. They find that startups listed on the portal use signals with regard to financial roadmaps, risk factors, and the internal governance of the firm that encourage crowd investors to participate. Block et al. (2016), Hornuf and Schwienbacher (2015), and Vismara (2015) investigate the funding dynamics in equity crowdfunding. They find that investors base their decisions on the information offered by the entrepreneur in the form of updates and by peer investments and comments of other crowd investors. Moreover, there is evidence for a collective attention effect and herding behavior.

In what follows, we analyze the pricing of cash flow rights in a start-up company by equity crowdfunding backers. In contrast with all other European equity crowdfunding portals, Innovestment deviates from brokering fixed-price investment tickets on a firstcome, first-served basis. Instead, the portal implemented a multi-unit second-price auction in which backers can themselves specify the price they are willing to pay for each ticket, with a lower threshold being specified by Innovestment and the start-up to be listed. As a consequence, backers can outbid each other when acquiring cash flow rights in a start-up company.

Our key contribution to the literature is to exploit this unique auction mechanism and present an analysis of backers' willingness to pay. We test whether (1) campaign characteristics, (2) investor sophistication, (3) the progress in the funding campaign, (4) herding behavior, (5) stock market volatility, (6) the distance between the backer and the start-up, and (7) sniping at the end of an auction play a role when backers decide how much money they are willing to pay for a ticket. Our sample consists of 44 campaigns that Innovestment accepted to be listed on its website. Our results are based on 1450 bids made by 499 backers during the period from November 6, 2011, to March 25, 2014.

Our key findings are that campaign characteristics, investor sophistication, progress in the funding campaign, herding, and stock market volatility influence backers' willingness to pay in an economically meaningful manner. We find no evidence that geographic distance, learning effects, or sniping behavior at the end of the auction influences the pricing of cash flow rights in a start-up company. The results suggest that self-imposed portal designs and the organization of equity crowdfunding campaigns can exert a strong impact on backers' willingness to pay for cash flow rights and company shares more generally.

The remainder of this paper proceeds as follows. Section 2 provides some background on equity crowdfunding in general and a detailed explanation of the auction mechanism of the equity crowdfunding portal Innovestment. Section 3 introduces the data set and derives the paper's hypotheses. Section 4 presents the empirical results. Section 5 concludes and provides policy implications.

\section{Theoretical and institutional background}

\subsection{Defining equity crowdfunding}

Crowdfunding combines the idea of micro-finance with crowdsourcing (Mollick 2013). In the USA, crowdfunding campaigns are run under either the donation or the reward model. Under the former, backers donate money to support a philanthropic project without expecting any compensation. Under the latter, backers are promised tangible or intangible perks, such as a supporter coffee mug or being mentioned on the campaign website. For some of the most popular projects, rewards resemble a pre-purchase of the product or service to be developed by the founder. In the case of the Pebble smartwatch, for example, 68,929 backers spent more than 10 million 
USD in total to obtain a watch that connects with the smartphone. The first 200 backers pre-purchased a black watch for 99 USD. Another 40,799 backers then prepaid 115 USD for the very same watch. The remaining backers prepaid a slightly higher amount to obtain a fancier version of the watch.

The crowdfunding business model is different from crowdlending, in which backers invest in consumer or business loans to receive a pre-determined periodic interest payment from debtors. Equity crowdfunding is a combination of crowdfunding and crowdlending. Backers spend money in equity crowdfunding campaigns to support a founder, who is working to develop a sustainable product or service, and expect a monetary return after the investment contract expires or the start-up company is bought by a venture capitalist. In the majority of the equity crowdfunding campaigns, however, backers do not pre-purchase the product or service to be developed. In the USA, equity crowdfunding was restricted for a long time to accredited investors and did not take place in any significant manner. Although in 2012 the USA was the first jurisdiction to pass a law specifically regulating equity crowdfunding activities, the Securities and Exchange Commission implemented specific rules on Title III of the Jumpstart Our Business Start-ups (JOBS) Act only in May 2016. At that time, equity crowdfunding by soliciting the general public became legal.

Under German securities law, equity crowdfunding by non-accredited investors has always been possible. Since 2011, more than 30 equity crowdfunding portals began operating. The crowd participates in the future cash flows of a firm by investing in mezzanine financial instruments. Most founders do not offer common shares in a private limited liability company (LLC), as a notary needs to be involved to allow for the transfer of such shares (Braun et al. 2013). Moreover, the minimum capital requirement as well as the operating costs of a public LLC (which does not require the involvement of a notary to transfer shares) often overburdens the founders of a start-up company. Common shares of a public LLC are therefore rarely used in equity crowdfunding campaigns. As a result, German start-ups most often use profit-participating loans, cooperative certificates, and silent partnerships when running an equity crowdfunding campaign, which then replicate the future cash flows of the firm.

\subsection{Innovestment}

One of the oldest German equity crowdfunding portals is Innovestment. The start-up particular completed its first successful campaign through the portal on December 25, 2011, the same year market leader and first-mover Seedmatch appeared on the equity crowdfunding market. In many respects, Innovestment is similar to Seedmatch and many other equity crowdfunding portals in Europe (Hornuf and Schwienbacher 2014). Before a campaign goes online, Innovestment and the founders must agree on a valuation of the startup, and even before that, the founders of the start-up must decide how much capital they want to raise. After considering the financial needs of the firm and the value of the firm that was negotiated, Innovestment adapts a standardized financial contract (a silent partnership agreement) replicating an equity share in the start-up. Becoming a silent partner allows investors to participate in the future cash flows of the firm during the lifespan of the contract and again when the silent partnership agreement expires.

Many start-ups running campaigns on Innovestment intended to raise EUR 100,000 and offered EUR 1000 investment tickets to backers. If the initial valuation of the start-up was, for example, negotiated to be EUR 1,000,000 and the firm raised EUR 100,000 , backers buying a single investment ticket obtained a right on $0.091 \%$ of the cash flow, provided that the price of the investment ticket did not rise during the auction. It is important to note that backers who ultimately become silent partners of a start-up do not receive any of the rights attached to a common equity share, such as voting rights; however, they also do not participate in the losses of the start-up. Furthermore, the silent partnership agreements Innovestment uses are senior to ordinary shares and shareholder loans but rank after all ordinary liabilities. These usually expire after three to 7 years and cannot be traded on a secondary market after the initial allotment takes place.

While in many respects Innovestment is similar to all other European equity crowdfunding portals, it also differs in one important respect and therefore is worth analyzing in further detail. European equity crowdfunding portals uniformly allocate equity shares or one of the aforementioned financial instruments through a fixed-price first-come, first-served allocation mechanism. That is, the portal stipulates a fixed price per 
investment ticket that usually applies for all its investors and campaigns. The number of tickets being offered during a campaign is then determined by the overall funding limit as defined by the founders and the fixed price per ticket. The lower the price per ticket, the more tickets can be sold given the particular funding limit. As a result, the portal stops selling silent partnership agreements to the crowd when the funding limit and, thus, the pre-determined number of tickets are reached.

Innovestment has deviated from stipulating a fixed price per investment ticket and instead has adapted a multi-unit second-price auction. In theory, under a sealed-bid second-price auction, a dominant strategy for backers is to reveal their true willingness to pay for the cash flow rights in a start-up company (Kagel and Levin 2001). The Innovestment auction is particular as it involves three stages. Before describing these three stages in more detail, we note that it is only at the end of a pre-determined funding period (usually 30 days $^{2}$ ) that units are allotted to the investors and a legal transfer of money as well as silent partnership agreements takes place. Before that, backers only commit to buying cash flow rights according to their bids, and funds are frozen on a trust account. Moreover, the portal reveals only three types of information to backers: the current price per ticket, the overall funding amount reached, and, thus, whether the funding goal was reached or not. Nevertheless, individual bids by other investors are sealed (see Fig. 3 in the 'Appendix' for the entry mask).

During the first phase of the auction, backers can make pledges by specifying the number of tickets they want to buy and the price they are willing to pay for each ticket. Innovestment and the start-up determine a lower threshold for the price of a single investment ticket, which is often determined to be EUR 1000. Everyone who pledges money is allotted the desired number of tickets during the first phase of the auction, and the lowest bid applies to everyone. In principle, there is no reason for investors to outbid the lower threshold at this phase, as there is yet no scarcity in tickets and indicating their true willingness to pay would only drive up the price per ticket. However, backers may anticipate that the auction will run in the second phase and indicate their true willingness to pay

\footnotetext{
${ }^{2}$ Chemla and Tinn (2016) show theoretically that a limited campaign length is essential to overcome moral hazard.
}

for cash flow rights from the outset to avoid the potential transactions cost of being outbid and bidding again later. ${ }^{3}$ Importantly, the Innovestment auction also operates under an all-or-nothing funding model (Cumming et al. 2015). Under this model, Innovestment and the start-up determine a minimum funding goal that needs to be reached within a pre-determined funding period. If the minimum funding goal is not reached within this time frame, the capital pledged by the backers is returned to them.

The second phase of the auction begins when a predetermined number of investment tickets are sold to the crowd. The number of tickets, and thus the beginning of the second stage of the auction, is not known to the Innovestment backers until the second stage is finally reached. The number of investment tickets sold by the end of the first auction phase also determines the number that is available throughout the second phase and is then kept constant. From now on, investors can only outbid each other by posting higher prices. Backers anticipating that the second stage of the auction will be reached should now rationally reveal their true willingness to pay, given that this phase of the Innovestment auction is equivalent to a Vickrey (1961) auction. Importantly, the second phase of the auction is not restricted to investors from the first phase. Every investor who is registered on the portal can still join the bidding process. The second phase continues until the funding limit is reached. After that, the auction enters the third stage, during which all registered users can still outbid investors. At this point, however, it is no longer possible to increase the overall sum of funds received by the start-up. Higher bids consequently result in the overall number of investment tickets being reduced. Because the overall sum of funds stays constant, while the number of tickets is reduced, the cash flow rights the start-up must sell for a given amount of capital are decreased. ${ }^{4}$

What should be clear to the crowd is that the different phases of the auction mechanism have no hard-ending rule; that is, silent partnership agreements

\footnotetext{
3 Indeed, the CEO of Innovestment made this argument when she was asked why investors overbid the lower price threshold during the first phase of the auction.

4 The second phase of the auction was abolished from November 1, 2012, onward. Consequently, the first phase continued until the funding limit was reached. Thereafter, the third phase started immediately. In the empirical analysis, we take this change in portal design into account.
} 
cannot sell out as their availability only depends on backers' willingness to pay. Everyone can invest at each phase of the auction until the pre-determined funding period ends. Thus, unlike under the fixedprice first-come, first-served allocation mechanism, in which it might be risky for the crowd to postpone an investment decision, investors have an incentive to reveal their true willingness to pay and may theoretically invest at any time of the funding period under the multi-unit second-price auction mechanism.

\section{Empirical methodology and data}

Our data set consists of 42 start-ups that used the equity crowdfunding portal Innovestment for their funding campaigns during the period from November 6, 2011, to March 25, 2014. In total, we observe 1627 bids for 44 funding campaigns, ${ }^{5}$ with a total volume of EUR 4,525,062 pledged. Total bids by individuals over the 2.5-year period vary from EUR 500 to EUR 149,839 . Due to data availability issues for some of the explanatory variables (average income according to postal code; see subsequently), our sample contains 1450 bids made by 499 backers.

\subsection{Dependent variable: premium over ticket price}

As the dependent variable, we measure backers' willingness to pay for cash flow rights by calculating the relative 'premium' over the initial ticket price in percentage:

Premium $=100 \times \frac{\text { Offered } \text { price }- \text { Ticket price }}{\text { Ticket price }}$

Table 1 shows descriptive statistics for the observed premia. Figure 1 shows the distribution of the premia, split for several sub-groups. The first sub-group consists of all bids before the funding goal was reached, the second sub-group consists of all bids after the funding goal was reached, but before the funding limit was reached, and the third sub-group consists of all bids after the funding limit was reached.

Overall, 457 investment bids (31.5\% of all bids in the sample) are made without any premium. Most of

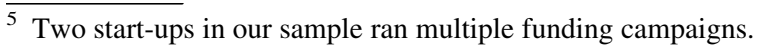

these bids were made before the funding goal was reached $(370 ; 48.9 \% \text { of all bids in phase } 1)^{6}$ However, the fact that more than $50 \%$ of all bids in that sub-sample are made with a positive premium confirms that some backers avoid the transaction costs of bidding again later, even though posting a premium can drive up the second price in the first round of the auction.

The average premium over the ticket price is $18.3 \%$ and is increasing over the three sub-samples: It was $10.7 \%$ before the funding goal was reached, $13.7 \%$ after the funding goal was reached, and $35.3 \%$ after the funding limit was reached, and these differences are statistically significant. ${ }^{7}$ In addition, the standard deviation differs considerably across subgroups. It is 1.5 times as large in the third sub-group as in the first and second sub-groups, and this difference is also statistically significant. ${ }^{8}$ This is also reflected in the right panel of Fig. 1 which is more uniformly distributed over the different levels of premia than the left and middle panels.

Of the 499 backers in our sample, 255 (51.1\%) made a single pledge during the whole sample period, another $107(21.4 \%)$ pledged twice, and only 24 (4.8\%) made 11 pledges or more. In $527(36.3 \%)$ of the 1450 total bids, backers made a repeated pledge in one campaign. The maximum number of bids by one backer in one campaign is 11 . The average starting bid of first-time bidders before the funding goal was reached is $10.8 \%(n=310)$, which is almost the same as the overall average bid during that phase $(10.7 \%$, $n=757$, see also Table 1), implying that there are no differences between first-time and more experienced bidders.

To account for the abolition of the second phase of the auction on November 1, 2012, and to investigate

\footnotetext{
${ }^{6}$ The start of the second or third stage of the auction does not necessarily coincide with the funding goal or funding limit being reached.

7 The results of $t$ tests for differences in means across subgroups are as follows: goal not reached versus goal reached: $t=-2.17, p$ value $=0.03$; goal not reached versus limit reached: $t=-15.11, p$ value $=0.00$; goal reached versus limit reached: $-11.65, p$ value $=0.00$.

8 The results of variance-comparison tests across sub-groups are as follows: goal not reached versus goal reached: $f=1.12$, $p$ value $=0.27$; goal not reached versus limit reached: $f=0.49$, $p$ value $=0.00$; goal reached versus limit reached: $f=0.44$, $p$ value $=0.00$.
} 
Table 1 Descriptive statistics: premium over ticket price

\begin{tabular}{lllllrrr}
\hline & Mean & SD & Median & Min. & Max. & Obs. \\
\hline All & 18.32 & 25.87 & 8.00 & 0 & 203 & 1450 & 457 \\
Goal not reached & 10.67 & 20.81 & 1.00 & 0 & 203 & 757 \\
Goal reached & 13.70 & 19.68 & 9.13 & 0 & 150 & 281 & 86 \\
Limit reached & 35.53 & 29.67 & 29.80 & 0 & 203 & 412 \\
\hline
\end{tabular}

Column ' 0 ' indicates the frequency of bids without any premium
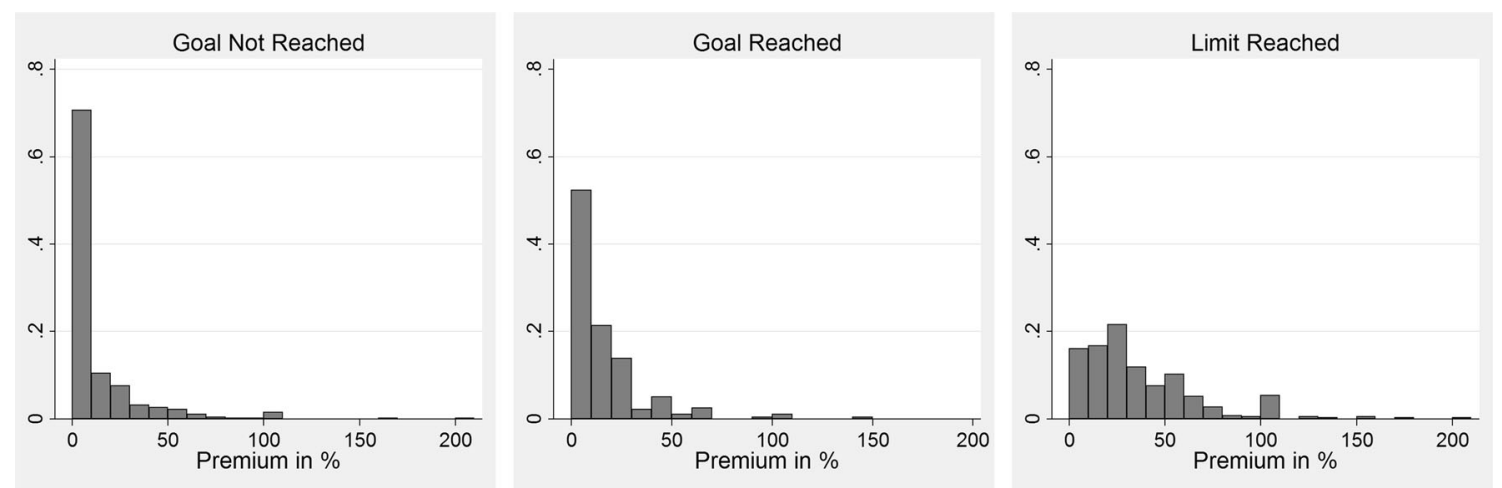

Fig. 1 Distribution of premia over ticket price. Note: $y$-axis shows the relative frequency of premia in the three phases of the auction

whether investors adapt their willingness to pay over time, we plot the premia against the number of pledges an investor had already made at the time of the focal pledge for the two sub-samples from November 6 , 2011, to November 1, 2012, and from November 2, 2012, to March 25, 2014. Figure 2 shows that during the second sub-sample, investors' mean unconditional willingness to pay for an investment ticket remained largely constant when bidding. In the first sub-sample, however, we observe a hump-shaped pattern when the premia are plotted against the number of pledges. In general, we find that in the first period, investors' willingness to pay is much larger, with a mean premium paid of $22.7 \%(n=710)$, than that in the second period, with a mean premium paid of only $14.1 \%(n=740)$, and this difference is statistically significant. ${ }^{9}$ While the observed difference could be attributed to the abolition of the second stage of the auction after November 1, 2012, it might also be due to

\footnotetext{
9 The results of a $t$ test for differences in means across subgroups is as follows: premium November 6, 2011, to November 1, 2012 versus November 1, 2012, to March 25, 2014: $t=6.39$, $p$ value $=0.00$.
}

changes in the market environment, in which over time more portals provided funding opportunities and the additional competition drove down investors' willingness to pay.

In the empirical analysis that follows, we run a regression on the full sample of 1450 observations and further focus on the period from November 2, 2012, to March 25, 2014, to account for a potential structural break due to the change in the platform design. In addition, we truncate both the full sample and the second sub-sample by leaving out 164 and 50 observations, respectively, where we observe a premium larger than $50 \%$ to explore the robustness of our results. ${ }^{10}$

\footnotetext{
${ }_{10}$ This threshold corresponds to roughly two standard deviations in the observed premia. Another reason for leaving out relatively large premia is to avoid typing errors by the investors. For example, in 25 cases we observe a premium of $100 \%$, and it might be the case that investors wanted to buy two tickets without any premium instead of one ticket with a premium of $100 \%$.
} 


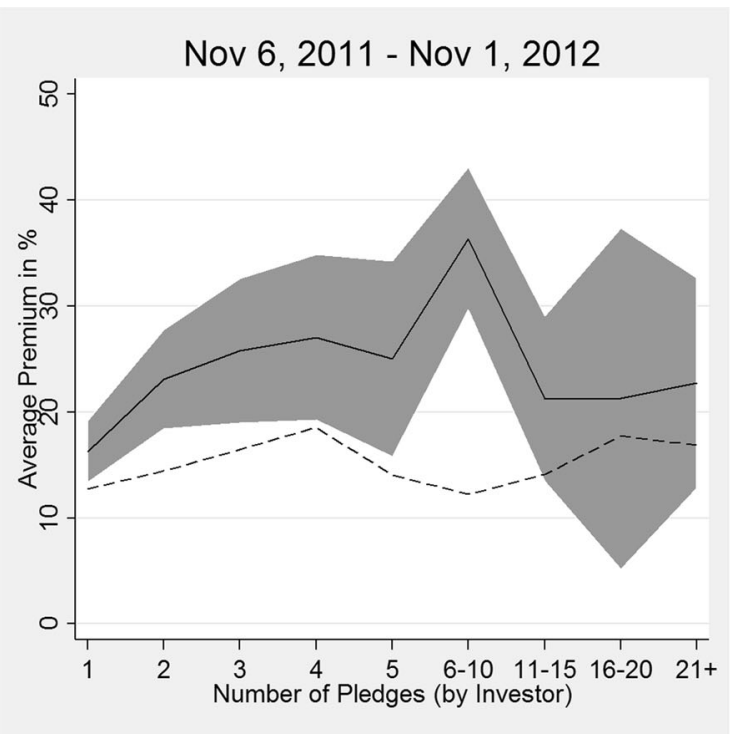

Fig. 2 Average premium and number of pledges (by investor). Note: The left (right) panel shows the average premium for different numbers of pledges at the time of the pledge (by

\subsection{Explanatory variables ${ }^{11}$ and hypotheses}

\subsubsection{Campaign characteristics}

Our first set of explanatory variables reflects campaign characteristics that are observable to all backers on the portal website. For each start-up, Innovestment reports an assessment of the firm's value, which varies from EUR 420,000 to EUR 10,000,000 in our sample of 44 funding campaigns. In addition, each firm must announce a funding goal, which varies from EUR 36,000 to EUR 150,000. We conjecture that the backers can interpret both the firm value and the funding goal as effective signals in the spirit of Spence (1973) for potentially lucrative investments. This is because the valuation and funding goal are both easily observable, and if chosen such that they are too high, they are costly for the founder because the campaign might receive not enough or no funding at all. For the funding goal, a higher funding goal signals to the crowd that the entrepreneur is confident that he or she will at least collect the pre-determined amount of money. If the threshold is not met, the money pledged is given back to the funders and the campaign fails.

\footnotetext{
11 Table 4 in the 'Appendix' reports descriptive statistics for the explanatory variables.
}

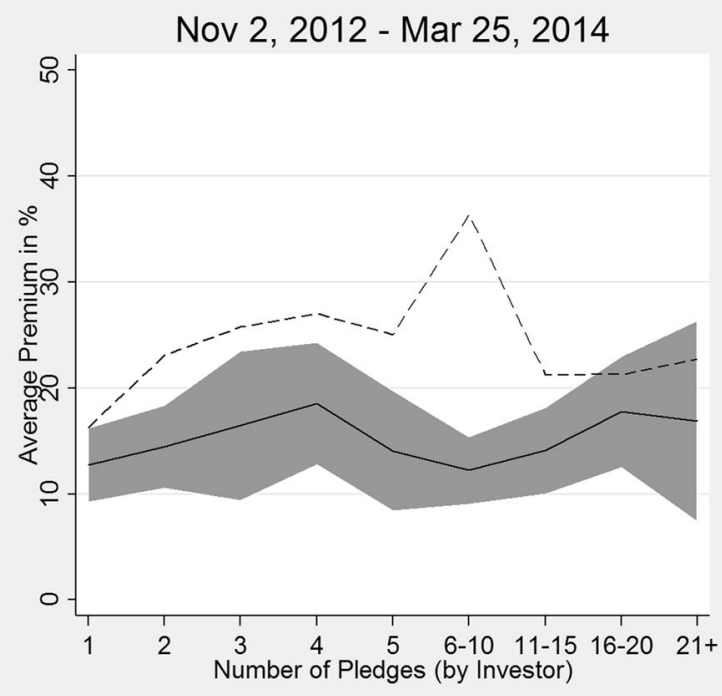

investor), along with $95 \%$ confidence bands during the first (second) sub-sample. The dashed lines represent the means from the respective other sub-sample

However, in case of the pre-valuation, there is also a channel that works in the opposite direction. A higher pre-valuation implies, for a single investment ticket, a lower share of future cash flows and, consequently, makes such an investment less attractive. Accordingly, our first hypothesis is as follows:

H1 The effect of the firm's pre-valuation on the premium is ambiguous. The premium is increasing in the funding goal.

\subsubsection{Backer sophistication}

We conjecture that more sophisticated backers understand the underlying auction mechanism better than their less sophisticated peers. As mentioned previously, we expect no extensive investment premia in the first phase of the auction, though backers anticipating the second stage of the auction might rationally post their reservation price, which may lie well above the minimum ticket price. In addition, we expect sophisticated backers to indicate their true willingness to pay for cash flow rights in the second and third stages. The differences across different types of backers might even be more relevant under transaction costs, as more sophisticated backers typically face relatively low costs when investing because they are more specialized in evaluating start-up companies. As 
we cannot make any conjectures about how the willingness to pay differs among sophisticated and unsophisticated investors, we do not specify a firm prior about conditional differences in the premium across these sub-groups.

We include a second set of explanatory variables that proxy backer sophistication. First, more sophisticated investors typically undertake relatively large investments. Consequently, we use the number of tickets a single investor bids for in a single pledge, which varies between 1 and 40, as an explanatory variable. Similarly, a higher minimum price per ticket as defined by Innovestment can serve as an entrance barrier for small investors. Thus, it is more likely that more sophisticated investors undertake bids if the minimum ticket price, which varies between EUR 500 and EUR 25,000, is relatively high. Moreover, backers might better understand how the auction mechanism works after pledging in multiple campaigns and become more sophisticated by investing more often on the portal. To capture possible learning effects, we consider how often a backer pledged on the portal before the current investment (see also Fig. 2). Next, Innovestment requires every backer to complete a short questionnaire about his or her investment experience in the following seven categories when registering with the portal: bonds, commodities, funds and certificates, real estate, stocks, term deposits, and other equity. Backers who claim to have experience in at least one of these categories conducted $52.3 \%$ of the bids. In the empirical analysis, we include a set of dummy variables for all seven categories, which take the value of 1 if a backer has experience in that particular category and 0 otherwise. Finally, Innovestment records the postal code of each backer. Thus, we are able to include the average income in the backer's home region in 2011, which varies between EUR 16,239 and EUR 28,900 in our sample, as a proxy for the backer's income and sophistication. ${ }^{12}$ Therefore, our second hypothesis is as follows:

H2 The premium will differ depending on the number of tickets bought, the price per ticket, the number of pledges the backer previously made, the backer's general investment experience, and the average income in the backer's home region.

\footnotetext{
12 We cannot retrieve this information for some of the foreign investors and, therefore, lose a part of the 1627 observations owing to the inclusion of this variable.
}

\subsubsection{Progress in the funding campaign}

A third hypothesis takes into account the progress in the funding campaign. Backers are well aware of the overall percentage of targeted funding accomplished at the time of their decision. Because the auction mechanism of Innovestment allows for bids even after the funding goal or limit has been reached, ${ }^{13}$ the accomplished funding share at the time of a bid varies between 0 and $100 \%$. Consequently, we include another explanatory variable that measures the funding share in percentage. In addition, backers know whether or not the funding goal or the funding limit has been reached. Thus, we also consider two non-disjunctive dummy variables, which measure (1) whether the funding goal was reached, but the funding limit has not yet been reached and (2) whether the funding limit has been reached. As reaching the funding goal removes the uncertainty in whether the funding actually takes place, backers with strong liquidity preferences no longer need to fear that they are simply putting their money on hold because the campaign in the end fails. ${ }^{14}$ Furthermore, reaching the funding goal and funding limit might be a signal of demand for the particular investment opportunity and the potential quality of the start-up. Thus, we expected a strong positive influence of these two dummy variables on the premium and, in particular, for the funding limit. Accordingly, our third hypothesis is as follows ${ }^{15}$ :

H3 The premium is increasing in the share of targeted funding, which has been accomplished and is higher if the funding goal or funding limit has been reached.

\subsubsection{Herding}

Herding is a well-documented phenomenon in financial markets (Scharfstein and Stein 1990), and it has

\footnotetext{
$\overline{13} 47.8 \%(28.4 \%)$ of all bids were recorded when the funding goal (limit) was reached.

${ }^{14}$ However, backers still can be outbid at this stage.

${ }^{15}$ We do not differentiate between the different stages of the auction in the empirical model, because including a dummy variable for the third stage of the auction alongside interaction terms of this dummy with the funding share, the funding goal, and the funding limit neither generates significant estimates nor changes the results of the other explanatory variables.
} 
also been observed in crowdlending (Herzenstein et al. 2011; Lee and Lee 2012) and equity crowdfunding (Hornuf and Schwienbacher 2015; Vismara 2015). To test whether herding affects the pricing of cash flow rights on Innovestment, we include the sum of investment bids in a start-up that were made earlier on the same day, as additional explanatory variable. The variation in this variable is surprising, as it is between EUR 0 and EUR 217,000. Thus, our next hypothesis aims to test whether herding behavior in equity crowdfunding affects the premium offered by backers:

H4 The premium is increasing in the sum of bids made earlier on the same day in a particular start-up.

\subsubsection{Stock market volatility}

Our sample period consists of episodes of financial market stress, in particular during the euro and sovereign debt crisis. Consequently, stock market volatility as measured by the German VDAX varies considerably over this period (between 11.47 and $37.28 \%$ ). Moreover, portfolio diversification of equity investors largely increased during the financial crisis as investors had a higher demand for similar but uncorrelated assets (Vermeulen 2013). Thus, if backers consider stocks and crowd investments substitutes, higher stock market volatility might lead to higher demand for this asset class and a larger premia being paid for crowd investments. ${ }^{16}$ Thus, our next hypothesis aims to detect such a substitution effect:

H5 The premium is increasing in stock market volatility.

\subsubsection{Distance backer/start-up}

We use the distance between the backer and the startup as an additional explanatory variable. This variable takes values between 0 and $644 \mathrm{~km}$ in our sample. A greater distance to a specific investment might imply higher search costs to obtain accurate information about a start-up and, as a consequence, a lower willingness to pay and a reduced premium. In addition, we observe a local bias in financial markets (Baltzer

\footnotetext{
${ }^{16}$ Dorn et al. (2015) document that investors consider investment and gambling products substitutes.
}

et al. 2015; Cumming and Dai 2010). Hornuf and Schmitt (2016) provide evidence that backers on Innovestment also exhibit a local bias. If backers have a higher demand for more local start-ups than for distant start-ups, a higher premium for geographically close firms could result. Both the aforementioned channels indicate a negative relationship between distance and premium, which leads to our sixth hypothesis:

H6 The premium is decreasing in the distance between the backer and the start-up.

\subsubsection{Sniping}

A well-known phenomenon in auctions is snipingthat is, the auction price increases drastically toward the end of the auction process (Ariely et al. 2005; Roth and Ockenfels 2002). As Innovestment posts the current second price that applies to everyone (see also Fig. 3 in the 'Appendix'), backers might bid late to avoid revealing information about their willingness to pay to other backers, which could ultimately drive up the price per ticket. Indeed, roughly $25 \%$ of the bids are made on the last day of the auction, which provides some descriptive evidence in favor of sniping. To test whether sniping is also relevant in a multivariate analysis, we include the remaining time measured in days as an additional explanatory variable. To test for potential nonlinearities and to capture the oftendocumented massive increase toward the end of the auction, we also include a quadratic term that measures squared remaining time in days. If sniping is prevalent, we would observe a negative sign; that is, the premium is lower the more time is remaining in the auction process. Thus, our last hypothesis is as follows:

H7 The premium is decreasing in the remaining time.

Table 2 provides an overview of all seven hypotheses and explanatory variables employed in the empirical analysis.

\subsection{Econometric model}

We explain the relative premium over the ticket price with all explanatory variables described in the previous sub-section. Econometrically, we use ordinary 
Table 2 Summary of hypotheses

\begin{tabular}{ll}
\hline H1: Campaign characteristics & H2: Backer sophistication $( \pm)$ \\
Pre-valuation $( \pm)$ & Number of tickets $( \pm)$ \\
Funding goal $(+)$ & Price per ticket $( \pm)$ \\
& Investment experience $( \pm)$ \\
H3: Progress in the funding campaign & Average income/region $( \pm)$ \\
Funding share $(+)$ & Number of pledges $( \pm)$ \\
Funding goal reached $(+)$ & \\
Funding limit reached $(+)$ & H4: herding $(+)$ \\
H5: Stock market volatility $(+)$ & H6: Distance backer/start-up $(-)$ \\
H7: Remaining time $(-)$ &
\end{tabular}

least squares and standard errors clustered at the backer level. ${ }^{17}$ In Sect. 4, we present four different sets of results. First, we show estimates that are based on the full sample of all 1450 observations. Second, we estimate the same model for the period from November 2, 2012, to March 25, 2014, using only 740 observations to account for a potential structural break due to the change in the platform design. In addition, we further truncate the sample and the second subsample, respectively, and explain the 1286 and 690 investments in which the premium is lower than or equal to $50 \%$ of the ticket price. In all regressions, we control for day-of-the-week effects, with Monday as the reference category.

\section{Empirical results}

Table 3 reports the results for the full sample period and all bids (column (1)). It also presents the results for the full sample period and bids with a premium of up to $50 \%$ (column (2)), for the second sub-sample from November 2, 2012, to March 25, 2014, and all bids (column (3)), and for the second sub-sample and bids with a premium of up to $50 \%$ (column (4)).

\footnotetext{
17 Our empirical model does not contain campaign-fixed effects. Otherwise, we would not be able to identify the effect of campaign characteristics (H1) and the price per ticket (H2) on the premium. In addition, our model does not contain backerfixed effects. Otherwise, we would not be able to identify the effect of experience $(\mathrm{H} 2)$, the average income in the investor's region $(\mathrm{H} 3)$, and the geographic distance $(\mathrm{H} 6)$ on the premium. Finally, our model does not contain time-fixed effects. Otherwise, it would be difficult to identify the effect of stock market volatility (H5) on the premium.
}

\subsection{Campaign characteristics}

In the regressions for the full sample period, we find that the premium is increasing in the size of the funding goal, which confirms H1. Backers are willing to offer a premium of 27.0 basis points (bps) (column (1)) and $6.7 \mathrm{bps}$ (column (2)) for each EUR 1000 increase in the funding goal, which evidences that the funding goal indeed serves as a signal to potential investors. To put this figure into perspective, we compare two groups of campaigns and use the more conservative estimate in column (2). In our data set, we have 15 campaigns with a funding goal of EUR 50,000 and another 14 campaigns with a funding goal of EUR 70,000. This difference of EUR 20,000 corresponds to a ceteris paribus difference of 1.34 percentage points (pp) in the premium. These findings are arguably driven by the first sub-sample, as the coefficients on the funding goal are no longer significant when we consider only the period after November 2, 2012. In contrast, firms' pre-valuation influences the size of the premium only in the second sub-sample. For each EUR 1000 increase in prevaluation, the premium increases by 0.5 bps (column (3)) and 0.3 bps (column (4)), respectively, which proves that a higher pre-valuation also serves as a signal for a potentially lucrative investment. The ceteris paribus difference for campaigns with prevaluations of EUR 800,000 and EUR 1,000,000 is $0.6 \mathrm{pp}$ (based on the estimates in column (4)). ${ }^{18}$

\footnotetext{
$\overline{18}$ Note that the differences in terms of (non-)significance of both variables across the different sets of results might be due to collinearity, as the bivariate correlation between pre-valuation and the funding goal is $\rho=0.76$.
} 
Table 3 Explaining equity crowdfunding premia

\begin{tabular}{|c|c|c|c|c|}
\hline & \multicolumn{2}{|l|}{ Full sample } & \multicolumn{2}{|c|}{ Nov 2, 2012-Mar 25, 2014} \\
\hline & $\begin{array}{l}\text { All bids } \\
\text { (1) }\end{array}$ & $\begin{array}{l}\text { Prem. } \leq 50 \% \\
\text { (2) }\end{array}$ & $\begin{array}{l}\text { All bids } \\
\text { (3) }\end{array}$ & $\begin{array}{l}\text { Prem. } \leq 50 \% \\
\text { (4) }\end{array}$ \\
\hline Pre-valuation & $\begin{array}{c}0.001 \\
(0.001)\end{array}$ & $\begin{array}{c}0.001 \\
(0.001)\end{array}$ & $\begin{array}{c}0.005^{*} \\
(0.002)\end{array}$ & $\begin{array}{c}0.003 * \\
(0.001)\end{array}$ \\
\hline Funding goal & $\begin{array}{l}0.270 * * \\
(0.053)\end{array}$ & $\begin{array}{l}0.067 * * \\
(0.024)\end{array}$ & $\begin{array}{c}-0.049 \\
(0.076)\end{array}$ & $\begin{array}{c}-0.042 \\
(0.045)\end{array}$ \\
\hline Number of tickets & $\begin{array}{c}0.309 \\
(0.197)\end{array}$ & $\begin{array}{c}0.146 \\
(0.089)\end{array}$ & $\begin{array}{c}0.226 \\
(0.201)\end{array}$ & $\begin{array}{c}0.193 * \\
(0.097)\end{array}$ \\
\hline Initial price/ticket & $\begin{array}{l}-0.928 \\
(0.633)\end{array}$ & $\begin{array}{c}-0.971^{* *} \\
(0.319)\end{array}$ & $\begin{array}{l}-1.613 \\
(0.970)\end{array}$ & $\begin{array}{c}-1.145 * \\
(0.465)\end{array}$ \\
\hline Bonds & $\begin{array}{c}-1.831 \\
(2.941)\end{array}$ & $\begin{array}{c}0.542 \\
(1.351)\end{array}$ & $\begin{array}{l}-2.593 \\
(3.469)\end{array}$ & $\begin{array}{c}-1.345 \\
(1.509)\end{array}$ \\
\hline Commodities & $\begin{array}{l}-3.320 \\
(2.705)\end{array}$ & $\begin{array}{l}-0.634 \\
(1.397)\end{array}$ & $\begin{array}{l}-0.312 \\
(3.373)\end{array}$ & $\begin{array}{c}0.478 \\
(1.639)\end{array}$ \\
\hline Funds/certificates & $\begin{array}{c}3.974 \\
(3.308)\end{array}$ & $\begin{array}{c}-0.004 \\
(1.805)\end{array}$ & $\begin{array}{c}5.702 \\
(4.281)\end{array}$ & $\begin{array}{l}-1.216 \\
(2.085)\end{array}$ \\
\hline Real estate & $\begin{array}{r}-5.317 \\
(2.903)\end{array}$ & $\begin{array}{c}-2.842^{*} \\
(1.279)\end{array}$ & $\begin{array}{c}-9.809 * \\
(3.789)\end{array}$ & $\begin{array}{c}-5.375^{* *} \\
(1.536)\end{array}$ \\
\hline Stocks & $\begin{array}{c}3.787 \\
(2.779)\end{array}$ & $\begin{array}{c}3.145 \\
(1.777)\end{array}$ & $\begin{array}{c}9.367 * \\
(4.088)\end{array}$ & $\begin{array}{l}5.729 * * \\
(2.106)\end{array}$ \\
\hline Term deposits & $\begin{array}{c}-2.039 \\
(3.165)\end{array}$ & $\begin{array}{c}-1.777 \\
(1.515)\end{array}$ & $\begin{array}{c}-3.736 \\
(4.670)\end{array}$ & $\begin{array}{c}-0.326 \\
(1.528)\end{array}$ \\
\hline Other equity & $\begin{array}{c}2.936 \\
(2.290)\end{array}$ & $\begin{array}{c}0.877 \\
(1.094)\end{array}$ & $\begin{array}{c}-0.321 \\
(2.637)\end{array}$ & $\begin{array}{c}0.364 \\
(1.242)\end{array}$ \\
\hline Disposable income & $\begin{array}{c}0.112 \\
(0.292)\end{array}$ & $\begin{array}{c}0.119 \\
(0.146)\end{array}$ & $\begin{array}{c}0.584 \\
(0.423)\end{array}$ & $\begin{array}{c}0.178 \\
(0.187)\end{array}$ \\
\hline Number of previous pledges & $\begin{array}{c}0.059 \\
(0.099)\end{array}$ & $\begin{array}{l}0.168 * * \\
(0.037)\end{array}$ & $\begin{array}{c}-0.190 \\
(0.168)\end{array}$ & $\begin{array}{c}0.132 \\
(0.071)\end{array}$ \\
\hline Funding share & $\begin{array}{c}0.030 \\
(0.033)\end{array}$ & $\begin{array}{c}0.025 \\
(0.017)\end{array}$ & $\begin{array}{c}0.041 \\
(0.043)\end{array}$ & $\begin{array}{c}0.034 \\
(0.021)\end{array}$ \\
\hline Funding goal reached & $\begin{array}{c}3.729 \\
(2.334)\end{array}$ & $\begin{array}{l}3.513^{* *} \\
(1.168)\end{array}$ & $\begin{array}{l}-3.443 \\
(3.240)\end{array}$ & $\begin{array}{c}0.022 \\
(1.452)\end{array}$ \\
\hline Funding limit reached & $\begin{array}{l}17.748 * * \\
(2.369)\end{array}$ & $\begin{array}{l}6.640 * * \\
(1.109)\end{array}$ & $\begin{array}{c}9.021 * \\
(3.707)\end{array}$ & $\begin{array}{l}3.938 * * \\
(1.410)\end{array}$ \\
\hline Bids earlier that day & $\begin{array}{l}0.079 * * \\
(0.020)\end{array}$ & $\begin{array}{l}0.111^{* *} \\
(0.009)\end{array}$ & $\begin{array}{l}0.128^{* *} \\
(0.022)\end{array}$ & $\begin{array}{l}0.125^{* *} \\
(0.009)\end{array}$ \\
\hline VDAX & $\begin{array}{l}0.789 * * \\
(0.152)\end{array}$ & $\begin{array}{l}0.521^{* *} \\
(0.063)\end{array}$ & $\begin{array}{c}-1.130 * \\
(0.502)\end{array}$ & $\begin{array}{c}0.088 \\
(0.243)\end{array}$ \\
\hline Distance backer/start-up & $\begin{array}{c}0.225 \\
(0.381)\end{array}$ & $\begin{array}{c}-0.205 \\
(0.182)\end{array}$ & $\begin{array}{c}-0.308 \\
(0.502)\end{array}$ & $\begin{array}{c}-0.278 \\
(0.222)\end{array}$ \\
\hline Days remaining & $\begin{array}{c}-0.013 \\
(0.261)\end{array}$ & $\begin{array}{l}0.510 * * \\
(0.098)\end{array}$ & $\begin{array}{c}-0.207 \\
(0.236)\end{array}$ & $\begin{array}{l}0.422 * * \\
(0.126)\end{array}$ \\
\hline Days remaining ${ }^{2}$ & $\begin{array}{c}0.004 \\
(0.007)\end{array}$ & $\begin{array}{c}-0.012 * * \\
(0.003)\end{array}$ & $\begin{array}{c}0.014 * \\
(0.006)\end{array}$ & $\begin{array}{c}-0.011 * * \\
(0.003)\end{array}$ \\
\hline
\end{tabular}


Table 3 continued

\begin{tabular}{|c|c|c|c|c|}
\hline & \multicolumn{2}{|l|}{ Full sample } & \multicolumn{2}{|c|}{ Nov 2, 2012-Mar 25, 2014} \\
\hline & $\begin{array}{l}\text { All bids } \\
\text { (1) }\end{array}$ & $\begin{array}{l}\text { Prem. } \leq 50 \% \\
\text { (2) }\end{array}$ & $\begin{array}{l}\text { All bids } \\
\text { (3) }\end{array}$ & $\begin{array}{l}\text { Prem. } \leq 50 \% \\
\text { (4) }\end{array}$ \\
\hline Tuesday & $\begin{array}{l}-0.987 \\
(2.331)\end{array}$ & $\begin{array}{c}1.126 \\
(1.305)\end{array}$ & $\begin{array}{c}2.348 \\
(2.918)\end{array}$ & $\begin{array}{c}1.918 \\
(1.582)\end{array}$ \\
\hline Wednesday & $\begin{array}{l}-1.354 \\
(2.392)\end{array}$ & $\begin{array}{c}0.367 \\
(1.338)\end{array}$ & $\begin{array}{l}-0.270 \\
(2.175)\end{array}$ & $\begin{array}{c}-1.088 \\
(1.331)\end{array}$ \\
\hline Thursday & $\begin{array}{c}0.258 \\
(2.917)\end{array}$ & $\begin{array}{l}-0.677 \\
(1.254)\end{array}$ & $\begin{array}{c}4.734 \\
(3.476)\end{array}$ & $\begin{array}{l}-0.303 \\
(1.454)\end{array}$ \\
\hline Friday & $\begin{array}{c}2.588 \\
(2.728)\end{array}$ & $\begin{array}{c}0.158 \\
(1.340)\end{array}$ & $\begin{array}{c}8.900 * \\
(4.073)\end{array}$ & $\begin{array}{c}1.017 \\
(1.506)\end{array}$ \\
\hline Saturday & $\begin{array}{c}0.034 \\
(2.906)\end{array}$ & $\begin{array}{r}-1.083 \\
(1.410)\end{array}$ & $\begin{array}{c}5.493 \\
(3.022)\end{array}$ & $\begin{array}{c}0.012 \\
(1.523)\end{array}$ \\
\hline Sunday & $\begin{array}{c}1.375 \\
(2.722)\end{array}$ & $\begin{array}{c}1.402 \\
(1.278)\end{array}$ & $\begin{array}{c}8.018 * \\
(3.367)\end{array}$ & $\begin{array}{c}2.881 \\
(1.720)\end{array}$ \\
\hline Constant & $\begin{array}{c}-29.614 * * \\
(6.989)\end{array}$ & $\begin{array}{c}-15.751 * * \\
(3.694)\end{array}$ & $\begin{array}{c}2.997 \\
(11.729)\end{array}$ & $\begin{array}{l}-4.675 \\
(6.181)\end{array}$ \\
\hline Adjusted $R^{2}$ & 0.254 & 0.357 & 0.220 & 0.480 \\
\hline Exclusion test DotW & 0.74 & 1.23 & $2.18 *$ & 1.61 \\
\hline Observations & 1450 & 1286 & 740 & 690 \\
\hline
\end{tabular}

Dependent variable: premium (in percentage). Standard errors (clustered at the backer level) are in parentheses $* * *$ Significance at the $1 / 5 \%$ level

\subsection{Backer sophistication}

The estimates for our proxies of backer sophistication yield conflicting results. The premium increases in the number of tickets bought by 19.3 bps (column (4)) and in the number of prior pledges by an investor by 16.8 bps (column (2)). In addition, investors with experience in the stock market are willing to pay higher premia during the second sub-sample (9.8 pp in column (3) and $5.7 \mathrm{pp}$ in column (4)). In contrast, each EUR 1000 increase in the minimum price per ticket leads to a $0.97 \mathrm{pp}$ (column (2)) and $1.15 \mathrm{pp}$ (column (4)) decrease in the premium. This implies that the total difference between campaigns with EUR 500 tickets (6 campaigns) and EUR 1000 tickets (29 campaigns) is $48.6 \mathrm{bps}$ (based on the estimates in column (2)). Furthermore, backers with experience in real estate investments offer a significantly lower premium than backers without any experience in that category. One potential driver of this difference between -2.84 and $-9.81 \mathrm{pp}$ could be the experience in assessing a financing plan. Finally, the average income in the backer's region is insignificant in all estimations. In summary, similar to the descriptive analysis in the previous section, we find no conclusive differences between sophisticated and unsophisticated investors.

\subsection{Progress in the funding campaign}

Confirming H3, the progress in the funding campaign positively influences the premium backers offer. The premium of bids made after the funding goal was reached is, on average, $3.51 \mathrm{pp}$ larger than bids made before the goal was reached, but only in the complete sample period and for bids with a premium up to $50 \%$ (column (2)). Reaching the funding limit is significant in all four specifications as we observe an additional increase in the premia when the funding limit was reached. This increase varies between 3.98 and 17.75 pp. Finally, the accomplished funding share itself does not significantly influence the premium. 


\subsection{Herding}

For the sum of investment bids in a start-up, which were made earlier on the same day, we again observe positive and significant coefficients in all four models. The premium increases between 7.9 and 12.8 bps for each EUR 1000, which is a clear indication of herding behavior and confirms H4. Multiplying the point estimate of $11.1 \mathrm{bps}$ (column (2)) by the standard deviation of this variable (EUR 38.023) indicates that the variation in the premia caused by herding behavior is also economically relevant (4.22 pp).

\subsection{Stock market volatility}

For the full sample period, backers tend to bid higher premia during episodes of financial market stress and consider stocks and crowd investments substitutes. A one-unit increase in the VDAX leads to a $78.9 \mathrm{bps}$ (column (1)) and 52.1 bps (column (2)) larger premium. To put the latter point estimate into perspective, we consider the effect of a one standard deviation change in the VDAX (6.752\%). This backof-the-envelope calculation reveals that the VDAX accounts for a variation of $3.52 \mathrm{pp}$ in the premium. Similar to the findings for the funding goal, the results for stock market volatility are driven by the first subsample, as we even observe a negative and significant coefficient for this variable in the second sub-sample (column (3)).

\subsection{Distance between backer and start-up}

The distance between a backer and a start-up is insignificant in all four sets of results. Consequently, we find no evidence of distance influencing the premium paid, which rejects $\mathrm{H6}$.

\subsection{Sniping}

For the complete sample period and all observations, the point estimates for the days remaining and (days remaining $)^{2}$ are individually and jointly insignificant $(F(2,498)=1.43)$. When considering only premia up to $50 \%$, we find a hump-shaped influence of the remaining time on the premium in the complete sample period and in the second sub-sample starting on November 2, 2012. From 0 to 21 (19) days remaining in the full sample period (second sub- sample), the premium is increasing; thereafter, it is decreasing. ${ }^{19}$ We interpret this as backers posting their reservation price at some point during the auction, which is well in line with the dominant strategy in Vickrey auctions. Another explanation for the finding is that Innovestment extends the funding period consecutively for another $15 \mathrm{~min}$ if additional bids are made toward the end of the campaign, which makes sniping literally impossible. Consequently, we find no evidence for sniping behavior toward the end of the auction, which rejects $\mathrm{H} 7$.

Finally, we can exclude day-of-the-week effects in three of the four models (columns (1), (2), and (4)). For the second sub-sample and all bids (column (3)), bids on Fridays and Sundays are 8.90 and 8.02 pp higher, respectively, than the reference day (Monday).

\section{Conclusion}

In this paper, we analyze the pricing of cash flow rights in start-up companies using a unique data set of equity crowdfunding backers. Our sample consists of 44 campaigns and includes 1450 bids made by 499 backers during the period from November 6, 2011, to March 25, 2014, on the German equity crowdfunding portal Innovestment. In contrast with all other European equity crowdfunding portals, Innovestment runs a multi-unit second-price auction in which backers can specify the price they are willing to pay for an investment ticket, with the portal and start-up specifying a lower threshold. We exploit this unique auction mechanism to analyze backers' willingness to pay for cash flow rights in a start-up company.

First, campaign characteristics play a meaningful role in the determination of backers' willingness to pay. Both the funding goal and pre-valuation serve as signals for potentially lucrative investments, as an increase in these variables is associated with a higher premium. Second, the estimates for backer sophistication yield conflicting results. The premium increases in the number of tickets bought and in the number of prior pledges by an investor but decreases in the minimum price per ticket. Backers with experience in real estate investments (the stock market) offer, on average, a lower (higher) premium than their

\footnotetext{
19 Note that the U-shaped pattern in column (3) is not significant for 0-28 days remaining.
} 
counterparts without any experience in the respective class of assets. Third, market forces are also of particular relevance, as reaching the funding goal leads to an increase in the premium (compared with investments in which the funding goal has not been reached), as does reaching the funding limit with an additional significant increase. Fourth, backers respond to the sum of investment bids in a start-up, which were made earlier on the same day, by increasing the premium in their bids. Fifth, backers tend to bid higher premia during episodes of financial market stress and consider stocks and crowd investments substitutes. We find this effect, however, only for the first sub-sample from November 6, 2011, to November 1, 2012.

In contrast, we find that geographic distance, learning effects, and sniping do not affect the premium paid. If backers were to indicate their true willingness to pay only at the end of the auction, as is regularly the case on eBay (Roth and Ockenfels 2002), there might be a risk that some bids are not successfully transmitted and investors with a higher willingness to pay are locked out. Our results do not indicate that this is the case in equity crowdfunding that takes place under a multi-unit second-price auction. Conversely, under a first-come, first-served mechanism with a hard-ending rule, investment tickets might quickly sell out (Hornuf and Schwienbacher 2016) and investors with a higher willingness to pay could be inefficiently debarred. Whether equity crowdfunding portals should adopt an auction mechanism, however, also depends on the returns that inventors earn and whether their bids exceed the value of the auctioned asset. A promising avenue for future research would be to test the auction mechanism after data on insolvencies, and actual payouts of the funded firms become available.

Our results contribute to the literature on portal design and campaign characteristics in equity crowdfunding. They suggest that portal design and the specific features of how an equity crowdfunding campaign is run significantly influence backers' willingness to pay for future cash flow rights in a start-up. This is also in line with prior studies that find that campaign characteristics such as the amount of equity offered and financial projections matter for funding success (Ahlers et al. 2015). Furthermore, in line with Hornuf and Schwienbacher (2015) and Vismara (2015), who find that information cascades determine funding success in equity crowdfunding, our results provide evidence that herding also affects backers' willingness to pay for shares in a start-up. As more data on the ultimate success and failure of startups become available, it would be promising to investigate whether herding in the context of equity crowdfunding is rational or irrational. On the one hand, some investors might rationally rely on the behavior of others because information costs are high. On the other hand, the crowd could also make faulty decisions by engaging in what has been termed 'groupthink' (Janis 1972). If it were necessary to guard investors from herding, equity crowdfunding portals that run an auction mechanism could implement some of the rules that are common to electronic trading systems on regular stock markets.

Acknowledgments Open access funding provided by Max Planck Society. This article evolved as part of the research project "Crowdinvesting in Germany, England and the USA: Regulatory Perspectives and Welfare Implications of a New Financing Scheme," which was supported by the German Research Foundation (Deutsche Forschungsgemeinschaft) under the grant number HO 5296/1-1. The authors are highly indebted to the managers and owners of Innovestment who provided the investor data as well as Matthias Schmitt who calculated the data on geographic distances. They also thank Gregor Dorfleitner, Lars Klöhn, Alexander Rajko, Elisabeth Schulte, the anonymous referee, and participants of the 3 . Crowdinvesting Symposium (University of Munich) and Munich Summer Institute 2016 (Bavarian Academy of Sciences and Humanities), who provided valuable comments and suggestions on previous versions of the paper.

Open Access This article is distributed under the terms of the Creative Commons Attribution 4.0 International License (http:// creativecommons.org/licenses/by/4.0/), which permits unrestricted use, distribution, and reproduction in any medium, provided you give appropriate credit to the original author(s) and the source, provide a link to the Creative Commons license, and indicate if changes were made.

\section{Appendix}

See Fig. 3 and Table 4. 


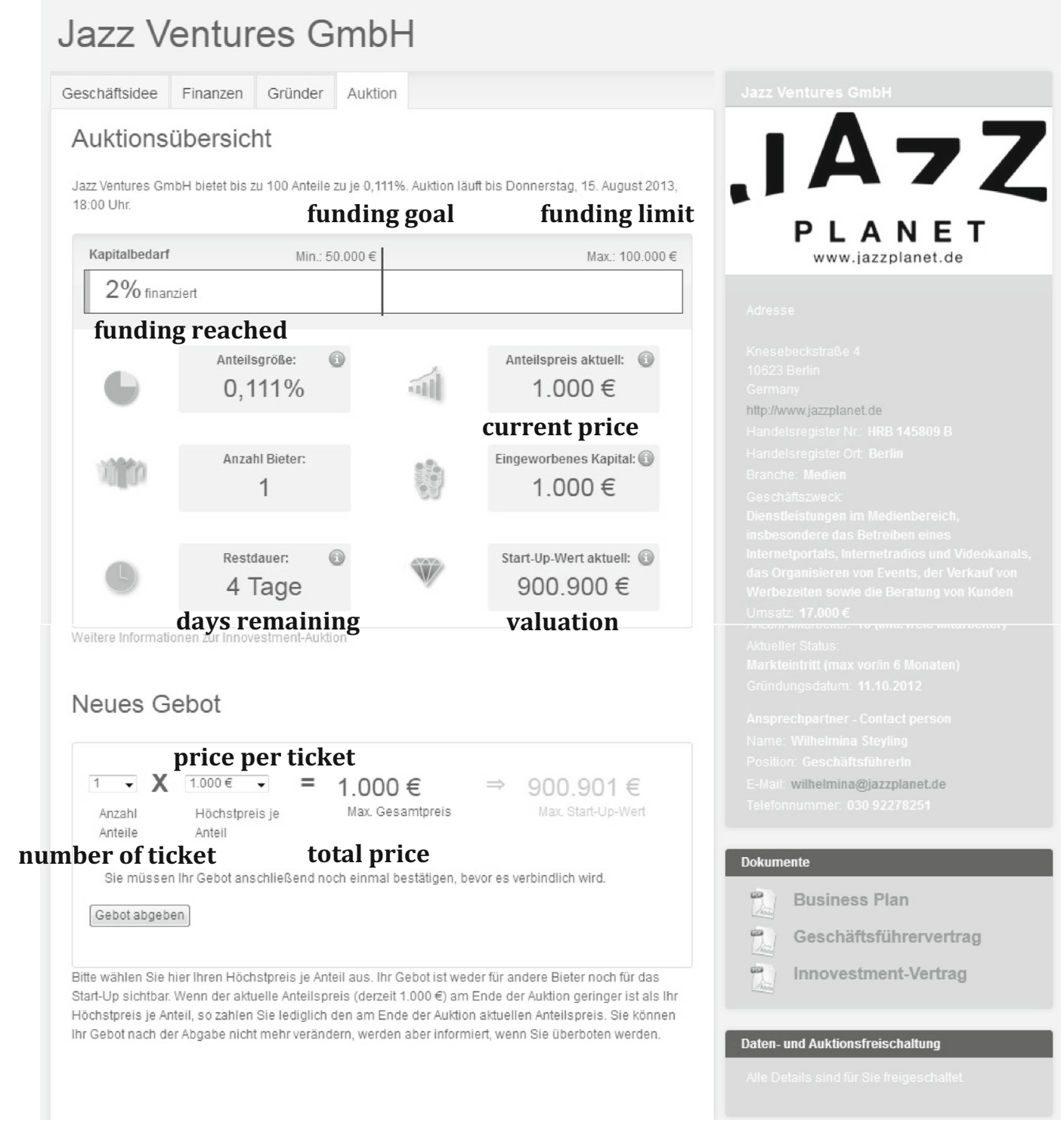

Fig. 3 Auction entry mask 
Table 4 Descriptive statistics of explanatory variables

\begin{tabular}{|c|c|c|c|c|c|c|}
\hline & Mean & SD & Min. & Max. & Yes & Corr \\
\hline Pre-valuation (in EUR 1000) & 1051.350 & 770.547 & 420 & 10,000 & & -0.047 \\
\hline Funding goal (in EUR 1000) & 60.325 & 14.904 & 36 & 150 & & 0.050 \\
\hline Number of tickets & 2.270 & 2.821 & 1 & 40 & & 0.019 \\
\hline Initial price/ticket (in EUR 1000) & 1.136 & 1.577 & 0.5 & 25 & & -0.019 \\
\hline Bonds & 0.303 & 0.460 & & & 439 & 0.005 \\
\hline Commodities & 0.228 & 0.420 & & & 331 & -0.030 \\
\hline Funds/certificates & 0.416 & 0.493 & & & 603 & 0.047 \\
\hline Real estate & 0.306 & 0.461 & & & 443 & -0.013 \\
\hline Stocks & 0.460 & 0.499 & & & 667 & 0.049 \\
\hline Term deposits & 0.434 & 0.496 & & & 629 & 0.025 \\
\hline Other equity & 0.309 & 0.462 & & & 448 & 0.036 \\
\hline Disposable income 2011 (in EUR 1000) & 21.219 & 2.569 & 16.239 & 28.900 & & 0.025 \\
\hline Number of previous pledges & 4.998 & 6.979 & 1 & 55 & & 0.030 \\
\hline Funding share (in \%) & 69.469 & 36.353 & 0 & 100 & & $0.240 * *$ \\
\hline Funding goal reached & 0.478 & 0.500 & & & 693 & $0.309 * *$ \\
\hline Funding limit reached & 0.284 & 0.451 & & & 412 & $0.419 * *$ \\
\hline Bids earlier that day (in EUR 1000) & 15.660 & 38.023 & 0 & 217 & & $0.227 * *$ \\
\hline VDAX (in \%) & 19.568 & 6.752 & 11.47 & 37.28 & & $0.271 * *$ \\
\hline Distance backer/start-up (in 100 km) & 2.942 & 1.758 & 0 & 6.440 & & 0.033 \\
\hline Days remaining & 14.911 & 14.101 & -0.047 & 76.058 & & $-0.061 *$ \\
\hline Tuesday & 0.112 & 0.316 & & & 163 & $-0.072 * *$ \\
\hline Wednesday & 0.157 & 0.364 & & & 228 & $-0.055^{*}$ \\
\hline Thursday & 0.114 & 0.318 & & & 165 & -0.045 \\
\hline Friday & 0.140 & 0.347 & & & 203 & -0.007 \\
\hline Saturday & 0.105 & 0.306 & & & 152 & -0.036 \\
\hline Sunday & 0.292 & 0.455 & & & 423 & $0.191 * *$ \\
\hline
\end{tabular}

Column 'Yes' indicates if a dummy variable takes the value of 1 . Column 'Corr' shows bivariate correlations with the premium **, * Significance at the $1 / 5 \%$ level

\section{References}

Agrawal, A., Catalini, C., \& Goldfarb, A. (2013). Crowdfunding: Social frictions in the flat world. NBER Working Paper 16820. http://www.nber.org/papers/w16820.

Ahlers, G., Cumming, D., Guenther, C., \& Schweizer, D. (2015). Equity crowdfunding. Entrepreneurship Theory and Practice, 39(4), 955-980. doi:10.1111/etap.12157.

Ariely, D., Ockenfels, A., \& Roth, A. E. (2005). An experimental analysis of ending rules in internet auctions. RAND Journal of Economics, 36(4), 891-908. doi:10.2139/ssrn. 429963.

Baltzer, M., Stolper, O., \& Walter, A. (2015). Home-field advantage or a matter of ambiguity aversion? Local bias among German individual investors. European Journal of Finance, 21(6), 734-754. doi:10.1080/1351847X.2013. 877514.

Belleflamme, P., Lambert, T., \& Schwienbacher, A. (2014). Crowdfunding: Tapping the right crowd. Journal of
Business Venturing, 29(5), 585-609. doi:10.1016/j. jbusvent.2013.07.003.

Block, J., Hornuf, L., \& Moritz, A. (2016). Which updates during an equity crowdfunding campaign increase crowd participation?" Trier Research Papers in Economics, No. 7/15. http://ssrn.com/abstract=2612998.

Bøg, M., Harmgart, H., Huck, S., \& Jeffers, A. M. (2012). Fundraising on the internet. Kyklos, 65(1), 18-30. doi:10. 1111/j.1467-6435.2011.00525.x.

Braun, R., Eidenmüller, H., Engert, A., \& Hornuf, L. (2013). Does charter competition foster entrepreneurship? A difference-in-difference approach to European company law reforms. Journal of Common Market Studies, 51(3), 399-415. doi:10.1111/jcms.12003.

Burtch, G., Ghose, A., \& Wattal, S. (2013). An empirical examination of the antecedents and consequences of investment patterns in crowd-funded markets. Information Systems Research, 24(3), 499-519. doi:10.2139/ssrn. 1928168. 
Burtch, G., Ghose, A., \& Wattal, S. (2014). Cultural differences and geography as determinants of online pro-social lending. MIS Quarterly, 38(3), 773-794. doi:10.2139/ssrn. 2271298.

Chemla, G., \& Tinn, K. (2016). Learning through crowdfunding. SSRN Working Paper. http://ssrn.com/abstract= 2796435.

Colombo, M. G., Franzoni, C., \& Rossi-Lamastra, C. (2015). Internal social capital and the attraction of early contributions in crowdfunding projects. Entrepreneurship Theory and Practice, 39(1), 75-100. doi:10.1111/etap.12118.

Cumming, D., \& Dai, N. (2010). Local bias in venture capital investments. Journal of Empirical Finance, 17, 362-380. doi:10.1016/j.jempfin.2009.11.001.

Cumming, D., Leboeuf, G., \& Schwienbacher, A. (2015). Crowdfunding models: keep-it-all versus all-or-nothing. Working Paper, http://leeds-faculty.colorado.edu/bhagat/ CrowdfundingModels-KeppItAll-AllorNothing.pdf.

Dorn, A., Dorn, D., \& Sengmueller, P. (2015). Trading as gambling. Management Science, 61(10), 2376-2393. doi:10.1287/mnsc.2014.1979.

Herzenstein, M., Dholakia, U., \& Andrews, R. (2011). Strategic herding behaviors in peer-to-peer loan auctions. Journal of Interactive Marketing, 25(1), 27-36. doi:10.1016/j.intmar. 2010.07.001.

Hornuf, L., \& Schmitt, M. (2016). Does a local bias exist in equity crowdfunding? The impact of investor types and portal design. Max Planck Institute for Innovation \& Competition Research Paper, No. 16-07. http://ssrn.com/ abstract $=2801170$.

Hornuf, L., \& Schwienbacher, A. (2014). The emergence of crowdinvesting in Europe. Munich Discussion Paper No. 2014-43. http://ssrn.com/abstract=2481994.

Hornuf, L., \& Schwienbacher, A. (2015). Funding dynamics in crowdinvesting. SSRN Working Paper. http://ssrn.com/ abstract $=2612998$.

Hornuf, L., \& Schwienbacher, A. (2016). Should securities regulation promote crowdinvesting? Small Business Economics, forthcoming.

Janis, I. (1972). Victims of groupthink: Psychological study of foreign-policy decisions and fiascos (2nd ed.). Boston, MA: Houghton Mifflin.

Kagel, J., \& Levin, D. (2001). Behavior in multi-unit demand auctions: Experiments with uniform price and dynamic Vickrey auctions. Econometrica, 69(2), 413-454. doi:10. 1111/1468-0262.00197.

Klöhn, L., \& Hornuf, L. (2012). Crowdinvesting in Deutschland: Markt, Rechtslage und Regulierungsperspektiven. Journal of Banking Law and Banking, 24(4), 237-266.

Knight, T. B., Leo, H., \& Ohmer, A. (2012). A very quiet revolution: A primer on securities crowdfunding and title of the JOBS act. Michigan Journal of Private Equity \& Venture Capital Law, 2, 135-153.

Koning, R., \& Model, J. (2013). Experimental study of crowdfunding cascades: When nothing is better than something. Academy of Management Proceedings, 2014(1), 16683. doi:10.5465/AMBPP.2014.16683abstract.

Kuppuswamy, V., \& Bayus, B. L. (2014). Crowdfunding creative ideas: The dynamics of project backers in Kickstarter. SSRN Working Paper. http://ssrn.com/abstract=2234765.
Lee, E., \& Lee, B. (2012). Herding behavior in online P2P lending: An empirical investigation. Electronic Commerce Research and Applications, 11(5), 495-503. doi:10.1016/j. elerap.2012.02.001.

Lin, M., Prabhala, N., \& Viswanathan, S. (2012). Judging borrowers by the company they keep: Friendship networks and information asymmetry in online peer to peer lending. Management Science, 59(1), 17-35. doi:10.1287/mnsc. 1120.1560.

Lin, M., \& Viswanathan, S. (2013). Home bias in online investments: An empirical study of an online crowdfunding market. Management Science, 62(5), 1393-1414. doi:10. 1287/mnsc.2015.2206.

Marom, D., \& Sade, O. (2013). Are the life and death of an early stage venture indeed in the power of the tongue? Lessons from online crowdfunding pitches. SSRN Working Paper. http://ssrn.com/abstract=2255707.

Meer, J. (2014). Effects of the price of charitable giving: Evidence from an online crowdfunding platform. Journal of Economic Behavior \& Organization, 103, 113-124. doi:10.3386/w19082.

Mollick, E. (2013). Swept away by the crowd? Crowdfunding, venture capital, and the selection of entrepreneurs. SSRN Working Paper. http://ssrn.com/abstract=2239204.

Mollick, E. (2014). The dynamics of crowdfunding: An exploratory study. Journal of Business Venturing, 29(1), 1-16. doi:10.1016/j.jbusvent.2013.06.005.

Roth, A., \& Ockenfels, A. (2002). Last-minute bidding and the rules for ending second-price auctions: Evidence from eBay and Amazon auctions on the internet. American Economic Review, 92(4), 1093-1103. doi:10.3386/w7729.

Saxton, G., \& Wang, L. (2014). The social network effect: The determinants of giving through social media. Nonprofit and Voluntary Sector Quarterly, 43(5), 1-19. doi:10.1177/ 0899764013485159.

Scharfstein, D., \& Stein, J. (1990). Herd behavior and investment. American Economic Review, 80(3), 465-479. doi:10. 1257/aer.90.3.705.

Spence, M. (1973). Job market signaling. Quarterly Journal of Economics, 87(3), 355-374. doi:10.2307/1882010.

Vermeulen, R. (2013). International diversification during the financial crisis: A blessing for equity investors? Journal of International Money and Finance, 35, 104-123. doi:10. 1016/j.jimonfin.2013.01.003.

Vickrey, W. (1961). Counterspeculation, auctions, and competitive sealed tenders. Journal of Finance, 16, 8-37. doi:10.1111/j.1540-6261.1961.tb02789.x.

Vismara, S. (2015). Information cascades among investors in equity crowdfunding. SSRN Working Paper. http://ssrn. com/abstract $=2589619$.

Younkin, P., \& Kashkooli, K. (2013). A crowd or a community? Comparing three explanations for the decision to donate to a crowdfunding project. https://www.funginstitute. berkeley.edu/sites/default/files/A_Crowd_Or_Community. pdf.

Zvilichovsky, D., Inbar, Y., \& Barzilay, O. (2013). Playing both sides of the market: Success and reciprocity on crowdfunding platforms. SSRN Working Paper. http://ssrn.com/ abstract $=2304101$. 